\title{
Comparative Histological Evaluation of The Effect of Platelet Rich Fibrin and Calcium Hydroxide as Capping Materials on Dog's Teeth Pulp
}

\author{
Hany G. Gobran' ${ }^{1}$ Ibrahim B. Farouk ${ }^{2}$, Hesham A. Dameer ${ }^{1}$
}

Codex : 10/2021/04

Aadj@azhar.edu.eg

\section{KEYWORDS}

Platelet Rich Fibrin,

Calcium hydroxide,

capping materials,

pulpotomy, dog's teeth pulp.

1. Department of Oral Biology, Faculty of Dental medicine, (Cairo, boys), Al-Azhar University, Egypt..

2. Department of Pedodontics and Oral Health, Faculty of Dental medicine, (Cairo, boys),AlAzhar University, Egypt.

* Corresponding Author e-mail: hanygobran.9@azhar.edu.eg

\begin{abstract}
Aim: It is to evaluate using of Platelet Rich Fibrin (PRF) And Calcium Hydroxide as a pulpotomy agent. Subjects and Methods : The present study was carried out on 9 adult healthy mongrel dogs which classified into 3 equal groups. Under general anesthesia, by means of split-mouth technique the dog's mandibular teeth were used. After the period of study, the animals were sacrificed by overdose of thiopental sodium and the lower jaw was excised with a bone saw. The study was carried out under the histological evaluation of cellular and pulp tissue response using H\&E stains. Results: The result of the present study revealed that, the early response of pulp tissue to all tested materials was inflammatory reactions, of various degrees, that were subsided by time completely only in PRF group. PRF has a powerful agent for regenerative effect on pulp tissue in an absence of dentin bridge formation. It also showed that, the PRF was well tolerated by pulp tissue of dogs' teeth. On the contrary, pulp degeneration and necrosis were the end results of pulpotomy with Calcium hydroxide agent. Conclusion: PRF can be more reliable than Calcium hydroxide in pulpotomy. PRF is the new material of choice that could be used as alternative to calcium hydroxide in pulpotomy.
\end{abstract}

\section{INTRODUCTION}

At present, despite improvements in oral health in different parts of the world, dental caries remains the most prevalent chronic oral disease that hazard the vitality of the teeth and its extension indicated for pulpal interventions ${ }^{(1)}$.The principal objective of pediatric operative dentistry is considered the conservative means as its main goal is the restoration of the pathologically affected teeth to healthy function until the date of its shedding, endodontic techniques facilitate the maintenance of pulpal compromised primary teeth, reducing the potential for unwanted sequelae of their unplanned extraction and subsequently maintenance of the normal pathway of its permanent successors that finally lead to normal occlusion and proper function. Managing pathologically or 
traumatically affected teeth, especially in young children, presents unique challenges to the clinicians who have a responsibility to provide effective land evidence based treatment for their pediatric patients. ${ }^{(2,3)}$ Several materials have been advocated to induce normal root development. For more than 70 years calcium hydroxide $(\mathrm{CH})$ has played a major role in endodontic therapy. It is the most commonly used dressing for treatment of the vital pulp. It also plays a major role as an inter- visit dressing in the disinfection of the root canal system especially in case of septic teeth due to its alkaline effect. Moreover $\mathrm{CH}$ pulpotomy may be precious and valuable treatment route for immature permanent teeth, even those associated with a radiographic image suggestive of periapical lesion. ${ }^{(4,5)} \mathrm{CH}$ as temporary dressing used between appointments promotes better results on the periapical healing process than the treatment in one appointment. ${ }^{(6)}$. The most dangerous factors that hazard the success rat of pulpotomy in primary teeth are necrosis, abscesses, internal and external resorption, and these occur more frequently with the use of $\mathrm{CH}$. Sealing of the cavity and restoration of the tooth are also factors in the failure of the technique.(7)

However calcium hydroxide has a limited antibacterial spectrum that does not affect all members of the endodontic microbiota that make its use only as intracanal medication is questionable. In addition, physicochemical properties of this substance may limit its effectiveness in disinfecting the entire root canal system after a short-term use. ${ }^{(5)}$ Not only internal resorption may result from over stimulation of the primary pulp by the highly alkaline $\mathrm{CH}$. But also induced over stimulation could cause metaplasia within the pulp tissue, leading to formation of odontoclasts. Also undetected microleakage could allow large numbers of bacteria to the pulp tissues and nullify the beneficial effects of $\mathrm{CH} .{ }^{(8)}$ Another disadvantage of $\mathrm{CH}$ including it does not exclusively stimulate dentinogenesis, may dissolve after one year with Cavo surface dissolution, may degrade during acid etching, degrades upon tooth flexure, marginal failure with amalgam condensation and does not adhere to dentin or resin restoration that leading to formation of dead space and subsequently bacterial invasion that may be leading to periapical pathos is and failure that hazard that maintenance of the tooth. ${ }^{(9)}$ Platelet Rich Fibrin (PRF) is autologous graft enhances wound healing and regeneration as concluded from several studies revealed that rapid and accelerated wound healing with the use of PRF than without it. PRF is superior to other platelet concentrates like (platelet rich plasma)PRP due to its ease and inexpensive method of preparation and also it does not need any addition of exogenous compounds like bovine thrombin and calcium chloride and considered more economic than PRP. (10) (PRF) is a powerful healing biomaterial with inherent regenerative capacity and can be used by itself or as scaffold in various procedures such as for the treatment of periodontal intra bony defects, treatment of furcation. Sinus lift procedures application in the field of tissue engineering. ${ }^{(11,12)}$ So that the purpose of this study is to evaluate using of PRF as a pulpotomy agent.

\section{MATERIALS AND METHODS}

The present study was carried out on 9 adult healthy mongrel dogs. The animals were classified into 3 equal groups according to the period of test: Group 1: three dogs were sacrificed after 3 weeks, Group 2: three dogs were sacrificed after 6 weeks, while Group 3: three dogs were sacrificed after 9 weeks. Each group was subdivided into two subgroups left side was $\mathrm{CH}$ group and right side was PRF group. in each group pulpotomy technique was carried out in lower premolar teeth. Under general anesthesia, the dog's mandibular teeth were prepared with class $\mathrm{V}$ cavities. A sample of blood is collected from each dog without anticoagulant in 10 $\mathrm{ml}$ tubes which are immediately centrifuged at a rate of $3000 \mathrm{rpm}$ for $10 \mathrm{~min}$. During the centrifugation process, when the blood gets in contact with the test tube wall the platelet gets activated leading 
to the initiation of coagulation cascade. After centrifugation, the resultant product consists of three layers. The top most layer consisting of a cellular (platelet poor plasma) PPP and PRF clot in the middle and RBCs at the bottom of the test tube. The fibrin clot obtained after centrifugation is removed by tweezer from the tube and the attached RBCs scraped off from it except $0.5 \mathrm{~mm}$ (which is newly formed and highly active) and discarded. Platelet rich fibrin PRF\& CH paste (2 tubes catalyst and base) were applied by means of split mouth technique PRF (Right side) and $\mathrm{CH}$ (Promedica) on left side). After drying with cotton pellets, the tested capping materials were gently applied over the orifices of radicular pulp of tested teeth; PRF and $\mathrm{CH}$ were applied. All cavities were restored with glass ionomer cement. After the period of study, the animals were sacrificed by overdose of thiopental sodium and the lower jaw was excised with a bone saw. After decalcification, all specimens were routinely processed with hematoxylin and eosin stain.for histological evaluations.

\section{RESULTS}

Group I ( three weeks intervals): left side CH group H\&E stain revealed that the radicular pulp tissues showing marked degree of degeneration of the pulp tissue with huge intercellular edema, large dilated blood vessels with thrombus formation,inflammatory cells infiltrate, variable marked reduction of odontoblastic layer on both sides and variable diss appearance of the predentine along the whole length of the radicular portion of the pulp that appears increase near to the exposure side than apex wise direction as shown in (Figure 1,A). While in right side PRF group H\&E stain demonstrated that the radicular pulp tissues had degeneration of the pulp tissue with intercellular edema, dilated blood vessels with RBCs with variable dimensions along the length of the radicular pulp tissue, inflammatory cells infiltrate, irregularities of predentine area and odontoblastic cells with variable thickness on both sides but overall with minimal as shown in (Figure1,B).

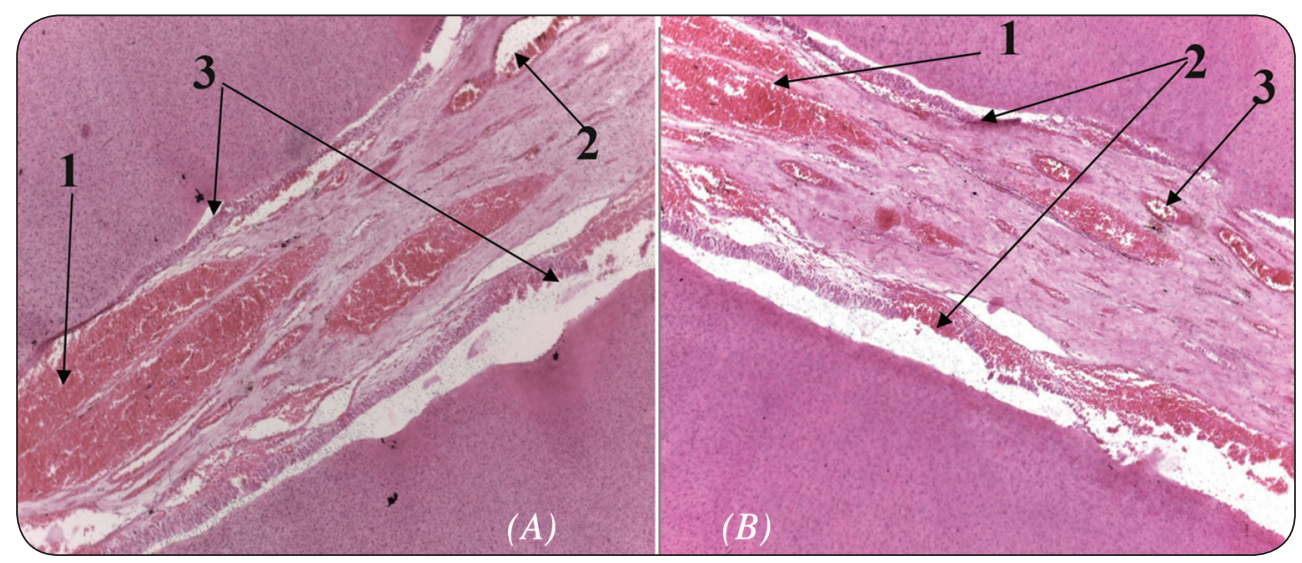

Fig. (1) Histological section of group I (three weeks intervals).(H\&E stain 100X).

(A) CH group showing:- (1) degeneration of the pulp tissue with huge intercellular edema (2), dilated blood vessels with thrombus formation, inflammatory cells infiltrate, (3)variable marked reduction of odontoblastic layer on both sides

(B) PRF group showing:- (1) degeneration of the pulp tissue with intercellular edema, dilated blood vessels with,inflammatory cells infiltrate, (2) Variable thickness of both predentine area and odontoblastic cells s on both sides . 
Group II after six weeks period: left side $\mathrm{CH}$ group H\&E stain revealed that the radicular pulp tissues showing degeneration of the pulp tissue with intercellular edema, large dilated blood vessels with thrombus formation, inflammatory cells infiltrate, irregularities of odontoblastic layer and predentine on both sides. The distribution of odontoblastic cells appeared highly aggregated on Rt side of the picture than Lt one which subsequently showing variation in odontoblastic layer thickness from side to another along the length of the radicular portion of the pulp as shown in (Figure 3, A). While in right side PRF group; H\&E stain demonstrated that the radicular pulp tissues starting the symphony of regeneration through the appearance of dentine bridges under the capping materials at the exposure site with marked reduction of all signs of degeneration. Intercellular edema, dilated blood vessels with RBCs with less marked variable dimensions along the length of the radicular pulp tissue, as well as inflammatory cells infiltrate. Recovery of predentine architecture area with odontoblastic cells distribution as shown in (Figure 3,B).
Group III after 9 weeks period: left side $\mathrm{CH}$ group H\&E stain revealed that the radicular pulp tissues showing delayed signs of regeneration through formation of thin layer of reparative dentine under the capping materials with still observation of some sort of degeneration of the radicular pulp tissue. Mild intercellular edema, large dilated blood vessels with thrombus formation, large calcification appeared within the pulp tissue. Irregularities of odontoblastic layer and predentine on both sides with minimal severity as before. The distribution of odontoblast appeared highly aggregated with marked variations from side to another as shown in (Figure 3, A). While in right side PRF group $H \& E$ stain demonstrated that the radicular pulp tissues nearly considered as normal pulp tissue with marked appearance of reparative dentine beneath the capping material and the exposure site. Coagulated blood vessels showed with highly minimal degree. Aggregation of odontoblast like cells appear under the reparative dentine as shown in(Figure3,B).
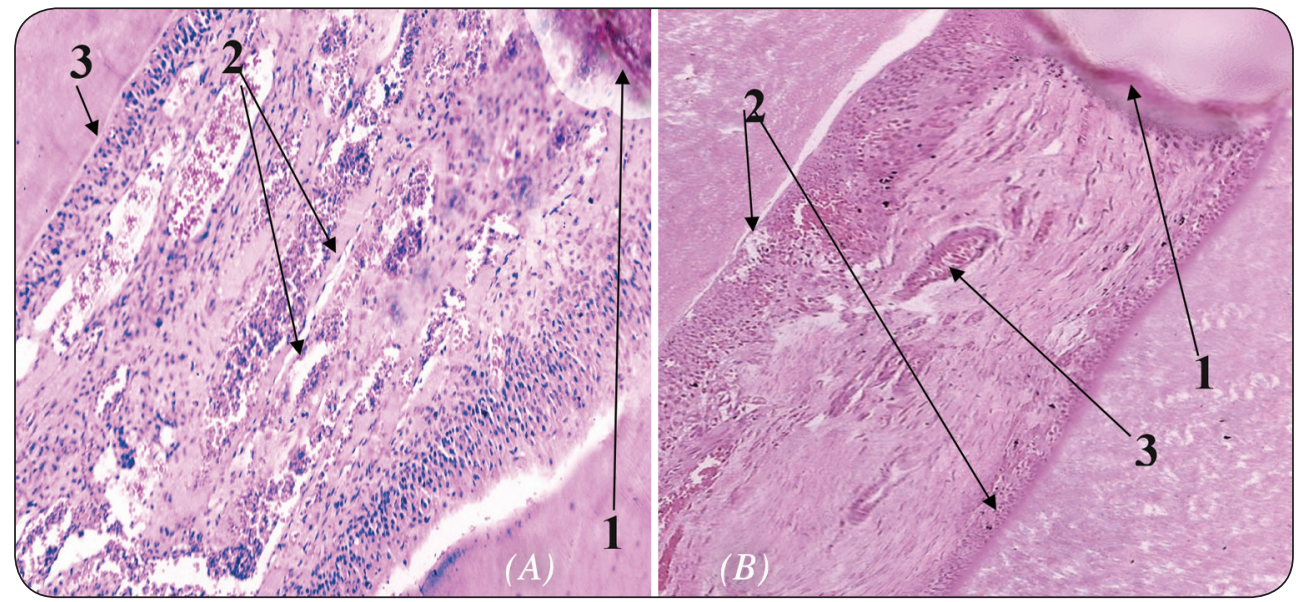

Fig. (2) Histological section of group II (Six weeks intervals).(H\&E stain 100X).

(A) CH group showing: - (1) capping material (2) degeneration of the pulp tissue with intercellular edema, dilated blood vessels with RBCs, inflammatory cells infiltrate, (3)Moderate aggregation of odontoblastic cells with variable predentine thickness on both sides.

(B) PRF group showing: - (1) Dentine bridge formation. (2) Highly aggregated odontoblastic cells with variable thickness. (3) reduced Intercellular edema, and dilated blood vessels with coagulated RBCs. 

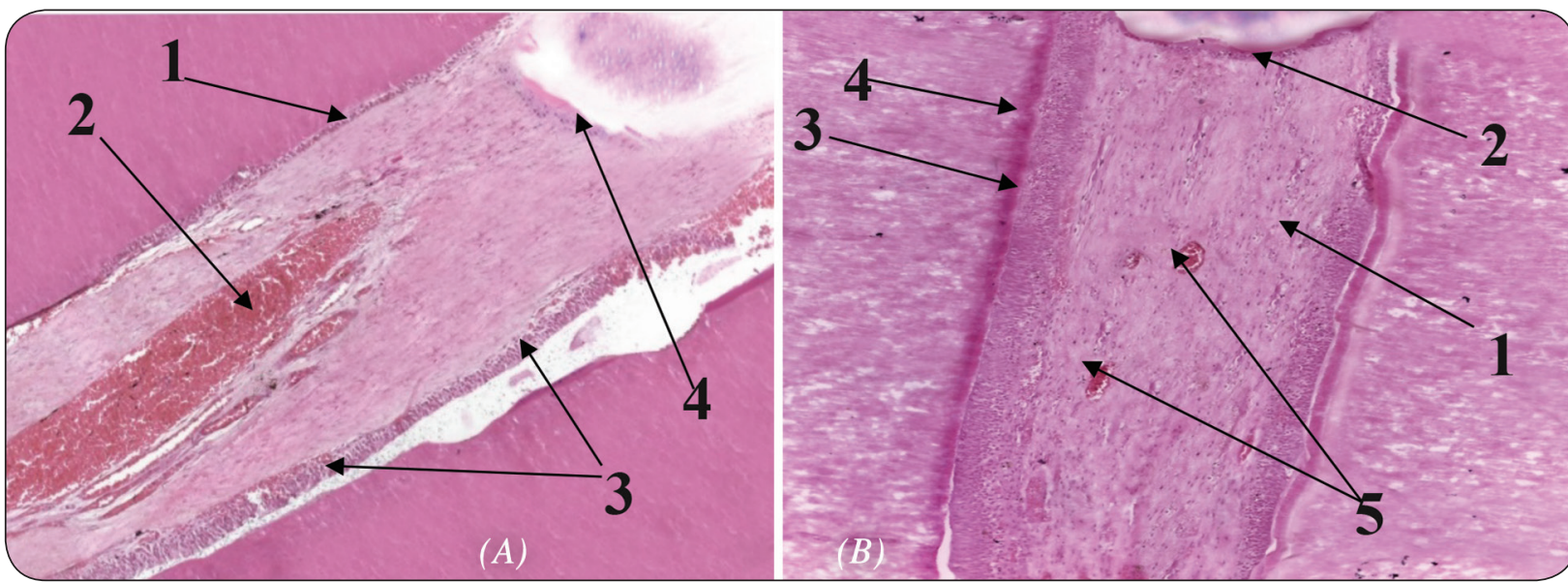

Fig. (3) Histological section of groupIII ( Nine weeks intervals).(H\&E stain 100X).

(A) CH group showing: (1) Thin rime of reparative dentine. (2) Calcified tissue, (3) Irregularities of predentine area and odontoblastic cells with variable thickness on both sides.(4)Thin rim of dentin bridge.

(B) PRF group showing 1) Nearly normal pulp tissue, (2) thick dentine bridge formation, (3) Highly aggregated odontoblastic cells, (4) predentine, (5) Small coagulated blood vessels.

\section{DISCUSSION}

Cavity preparation for pulpotomy in this research class I cavities were prepared to be more accurate for simulation to the most of clinical problems as most caries extension are occlusally or proximally and after capping the exposure to occlusal trauma may distort the effect of capping materials. This maneuver as point of view was conflict to the approach to the pulp by some authors who revealed that class $\mathrm{V}$ pulpotomy was easy and functional loads during biting could be avoided. ${ }^{(13-15)}$ Different histological parameters regarding pulpal wound healing following pulp capping with PRF were recorded in this study, including degree of inflammation of the pulpal tissue, thrombus formation, intercellular edema, irregularities of odontoblastic layer. However, results of the present study showed that inflammation was occurred in the both groups of the study but was less evident in PRF group than in $\mathrm{CH}$ group. Another study supported our finding as showed that, PRF includes dense fibrin network with leukocytes, cytokines, glycoproteins and growth factors. Basically leukocytes present in PRF have a key role in releasing of growth factors and anti-infectious ac- tivity. This explains, the relative existence of moderate inflammation of the pulpal tissue following pulp capping using PRF. ${ }^{(16,17)}$

Left side teeth capped with $\mathrm{CH}$ presented remarkably different results compared to Right side was in agreement with another interesting study ${ }^{(18)}$ who revealed that during the early time intervals, the specimens exhibited a conspicuous coagulation necrotic zone as a line delimiting the tissue in repair under the necrotic zone.other studies support our finding as concluded that, the initial response of $\mathrm{CH}$ as capping materials was destructive, which attributed to caustic effect of alkalinity of $\mathrm{CH}$ due to hydroxyl ions that leading to superficial necrosis of the pulp tissue. However, the retardation of regeneration of $\mathrm{CH}$ group was in agreement with who revealed that $\mathrm{CH}$ has several disadvantages including poor adherence to dentine, lack of long term seal and subsequently invasion of the bacteria to the remaining pulp tissue that finally retard pulp regeneration On the other hand histological evaluations of pulpal responses to vital pulp therapy with $\mathrm{CH}$ demonstrated that the dentinal bridge formation beneath $\mathrm{CH}$ was unpredictable. Moreover, 
pulps that were capped with $\mathrm{CH}$ were inflamed, dentin bridge was not formed in any of the subjects of group A due to severe inflammation. ${ }^{(19-21)}$ The histological finding after 9 weeks postoperatively demonstrated dramatic changes through the symphony of regeneration that reach to normal pulp tissues with normal architectures and formation of thick dentine bridges obviously appeared in animals treated by PRF. Some investigators were strongly support our observation in the current study as concluded that the effectiveness of PRF in accelerating wound healing of different tissues have been studied and proved previously Growth factors are critical in signaling the formation and repair processes in dentine-pulp complex and they signal many of the important events in tooth morphogenesis and differentiation, also recapitulation of these processes may lead to tissue regeneration. ${ }^{(22)}$ In addition micro vascularization develops in the fibrin network of PRF promotes cell migration and protein synthesis. ${ }^{(23)}$ On the other hand, the pulp tissue at the time of PRF group appeared normal, $\mathrm{CH}$ group showed marked reduction in regeneration through thin rim of dentine bridges showed that not completely seal the exposure site. Furthermore, presence of calcified tissue within the pulp. These finding was supported by other animal studies showed that, dentinal bridges formed beneath $\mathrm{CH}$ were in Lowe quality in terms of thickness and presence of tunnel defects. ${ }^{(25-26)}$

\section{CONCLUSION}

- Both PRF \&CH were reliable as pulpotomy agent.

- PRF is highly active autologous agent for maintaining of pulp vitality compared to $\mathrm{CH}$.

- PRF was better inductive material for pulp regeneration than $\mathrm{CH}$.

- PRF was biologically highly biocompatible agent as pulp capping material.

\section{REFERENCES}

1. Sma1 "1-Faugeron V, Courson F, Durieux P, et al. Pulp treatment for extensive decay in primary teeth. Cochrane Database Syst Rev. 2014;8:CD003220.

2. Hunter ML, Hunter B. Vital pulpotomy in the primary dentition: attitudes and practices of specialists in paediatric dentistry practising in the United Kingdom. Int J Paediatr Dent. 2003; 13: 246-50.

3. Despoina K, Peter D, Alex H, Monty D. Histological comparison of pulpal inflammation in primary teeth with occlusal or proximal caries. Int J Paediatr Dent. 2009; 19: 26-33.

4. Carrotte P. Endodontics: Part 9 calcium hydroxide, root resorption, endo-perio lesions. Br Dent J. 2004; 197:735-43.

5. Siqueira JF Jr, Lopes HP. Mechanisms of antimicrobial activity of calcium hydroxide: a critical review. Int Endod J. 1999 Sep; 32(5):361-69.

6. Estrela A, Holaland R. Calcium hydroxide: study based on scientific evidences. J Appl Oral Sci. 2003; 11: 269-82.

7. E. Stringhini Junior, M.E.B. Vitcel, L.B. OliveiraEvidence of pulpotomy in primary teeth comparing MTA, calcium hydroxide, ferric sulphate, and electrosurgery with formocresol Eur Arch Paediatr Dent. (2015) 16:303-312

8. Mustafa M. Saujanya KP, Jain D, Sajjanshetty S, Arun A, Uppin L.et al. Role of calcium hydroxide in endodontics: A review. Global J Med and Public Health. 2012; 1 : 53-57.

9. Foreman PC, Barnes IE. Review of calcium hydroxide. Int Endo J. 1990 Nov; 23(6): 283-97.

10. Sharma A, Pradeep AR. Treatment of 3-wall intrabony defects in patients with chronic periodontitis with autologous plateletrich fibrin: a randomized controlled clinical trial. J Periodontol 2011;82:1705-12.

11. Sharma A, Pradeep AR. Autologous platelet-rich fibrin in the treatment of mandibular degree II furcation defects: a randomized clinical trial. J Periodontol 2011; 82:1396-403.

12. Gassling V, Douglas T, Warnke PH, Acxil Y, Wiltfang J, Becker ST. Platelet-rich fibrin membranes as scaffolds for periosteal tissue engineering. Clin Oral Implants Res $2010 ; 21: 543-9$.

13. Sloan AJ, Smith AJ. Stimulation of the dentine-pulp complex of rat incisor teeth by transforming growth factor-beta isoforms 1-3 in vitro. Arch Oral Biol 1999; 44: 149-156.

14. Nakamura Y, Hammarström L, Lundberg E, Ekdahl H, Matsumoto K, Gestrelius S, Lyngstadaas SP. Enamel 
matrix derivative promotes reparative processes in the dental pulp. Adv Dental Res 2001; 15: 105-107.

15. Bidar M, Gharechahi M, Shahrami F, Safari MK, Forghani M. An in Vitro Evaluation of Coronal Microleakage Through Four Temporary Restorations by Dye Penetration. Jundishapur Sci Med J 2011; 6: 605-613.)

16. Aroca S, Keglevich T, Barbieri B, Gera I, Etienne D. Clinical evaluation of a modified coronally advanced flap alone or in combination with a platelet-rich fibrin membrane for the treatment of adjacent multiple gingival recessions: A 6-month study. J Periodontol 2009;80:244-52.

17. Kitamura C, Nishihara T, Ueno Y, Nagayoshi M, Kasugai $\mathrm{S}$, Terashita M. Thermotolerance of pulp cells and phagocytosis of apoptotic pulp cells by surviving pulp cells following heat stress. J Cell Biochem 2005; 94: 826-834.

18. Horsted-Bindslev P, Vilkinis V \& Sidlauskas A. Direct capping of human pulps with a dentin bonding system or with calcium hydroxide cement Oral Surgery, Oral Medicine, Oral Pathology, Oral Radiology, and Endodontics 2003:96:591-600.

19. Ford TR, Torabinejad M, Abedi HR, Bakland LK, Kariyawasam SP. Using mineral trioxide aggregate as a pulpcapping material. J Am Dent Assoc 1996; 127:1491-1494).

20. Parirokh M, Torabinejad M. Mineral trioxide aggregate: a comprehensive literature review-part III: clinical applications, drawbacks, and mechanism of action. J Endod 2010; 36:400-413.
21. Asgary S, Eghbal MJ, Ghoddusi J, Yazdani S. Oneyear results of vital pulp therapy in permanent molars with irreversible pulpitis: an ongoing multicenter, randomized, non-inferiority clinical trial. Clin Oral Investig 2013;17:431-439.

22. Preeja CA, Arun SB. Platelet-rich fibrin: Its role in periodontal regeneration. The Saudi Journal for Dental Research 2014; 5: 117-122

23. Giannobie WV, Hernandez RA, Finkelman RD, Comparative effects of platelet- derived growth factorBB and insulin-like growth factor-I, individually and in combination on periodontal regeneration in Macaca fascicularis. J Periodontal Res 1996;31:301.

24. Asgary S, Eghbal MJ, Parirokh M, Ghanavati F, Rahimi H. A comparative study of histologic response to different pulp capping materials and a novel endodontic cement. Oral Surg Oral Med Oral Pathol Oral Radiol Endod 2008;106:609-614. 11.

25. Nair PN, Duncan HF, Pitt Ford TR, Luder HU. Histological, ultrastructural and quantitative investigations on the response of healthy human pulps to experimental capping with mineral trioxide aggregate: a randomized controlled trial. Int Endod J 2008;41:128-150. 12.

26. Eghbal MJ, Asgary S, Baghlue RA, Parirokh M, Ghoddusi J. MTA pulpotomy of human permanent molars with irreversible pulpitis. Aust Endod J 2009;35:4-8. 


\title{
مقارنة هستولوجيه لتقييم مدي تأثير الصفائح الدموية الغنية

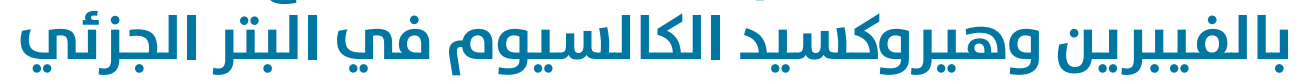 لب الب السنان في الكلاب
}

\author{
هاني جميل جبران, 1 ابراهيم فاروق بركات, 2 هشام احمد ضمير1

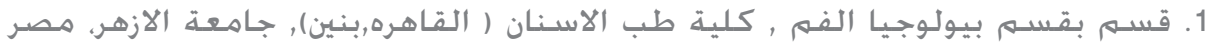

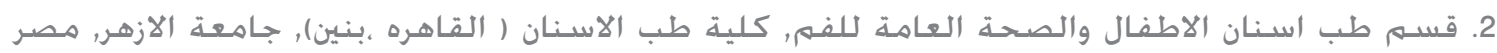

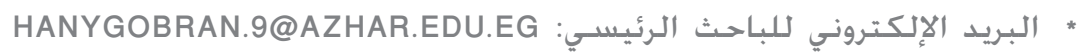

(الملخص:

الهدف : لقد تمت مقارنة تأثير استخدام الصفائح الدموية الغنية بالفيبرين واستخدام هيدروكسيد الكالسيوم كغطاء للب الاسنان المبتورة جزئيا في اسنان الكلاب.

المواد والأسـاليب : وتم تقييم هذه الدراسة هستولوجيا باستخدام صبغة الهيماتوكسيلين والايوسين بعد القتل الرحيم لكل مجمهوعة

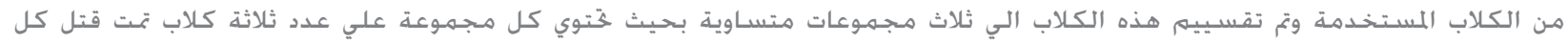

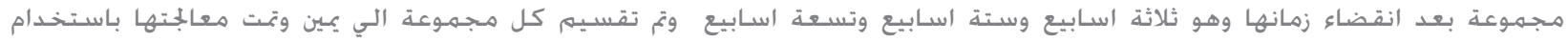

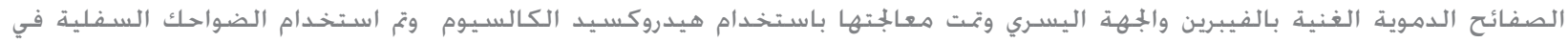
هذه التخجربة.

النتائج: أظهرت النتائج الاستجابة المبكرة لجميع المواد الخختبره بحدوث التهاب لعصب السن كاحد العلامات المبكره. والالياف الغنبه بالصفائح أظهرت قوه لتجدد المخلايا بصوره واضحة. النحانة الخلاصة : وقد خلصت الدراسة الي فاعلية استخدام مادة الصفائح الدموية الغنية بالفيبرين كغطاء للب الاسنان بعد البتر الجزئي لها

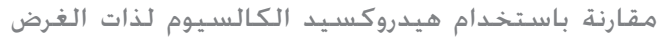
الكلمات المفتاحية: الصفائح الدموية الغنية بالفيبرين، هيدروكسيد الكالسيوم، غطاء للب الاسنان المبتورة، بتر لب السنه، لب اسنان الكلاب. 